\title{
Bacterial contamination of human skin allografts and antimicrobial resistance: a skin bank problem
}

\author{
Karine Lena Meneghetti, Micaela do Canto Canabarro, Letícia Muner Otton, Thaís dos Santos Hain,
} Mercedes Passos Geimba and Gertrudes Corção* (1)

\begin{abstract}
Background: Bacterial contamination remains the major problem in skin banks, even after antimicrobial treatment, and results in high rates of tissue discarding. This study aimed to analyze bacterial contamination in 32 human skin allografts from the skin bank of Dr. Roberto Corrêa Chem from the Hospital Complex Santa Casa de Misericórdia de Porto Alegre. These samples were already discarded due to microbial contamination. The identification of the bacteria isolated from skin allografts was performed by matrix assisted laser desorption ionization-time of flight. The antimicrobial susceptibility of the isolates to six different classes of antimicrobials was determined using the diskdiffusion agar method, and the evaluation of the inhibitory potential was determined by the minimal inhibitory concentration (50/90) of antimicrobials already used in the skin bank and those that most isolates were susceptible to.

Results: A total of 21 (65.6\%) skin samples were contaminated with Gram-positive bacteria: 1 (4.7\%) with Paenibacillus sp., 12 (61.9\%) with Bacillus sp., 6 (28.5\%) with Staphylococcus sp., and 2 (9.5\%) with Bacillus sp. and Staphylococcus sp. Several resistance profiles, including multiresistance, were found among the isolates. Most of the isolates were susceptible to at least one of the antimicrobials used in the skin bank. All isolates were susceptible to amikacin, gentamicin, and tetracycline, which demonstrated the best inhibitory activities against the isolates and were considered as potential candidates for new antimicrobial treatments.

Conclusions: Bacillus, Paenibacillus, and Staphylococcus were isolated from the skin allografts, thus demonstrating the predominance of Gram-positive bacteria contamination. Other factors not related to the resistance phenotype may also be involved in the persistence of bacterial isolates in the skin allografts after antibiotic treatment. Gentamicin, amikacin, and tetracycline can be considered as an option for a more effective treatment cocktail.
\end{abstract}

Keywords: Skin allograft, Bacterial contamination., Antimicrobial resistance., Skin bank., Discards.

\section{Background}

Skin allografts have been an efficient choice for the treatment of several skin lesions and have mainly been used for the temporary wound coverage of severe extensive burns [1]. The use of homologous skin grafts decreases the risk of infection, wound pain, and the frequency of dressing changes as it acts as a mechanical and biological barrier to reduce the loss of water, proteins, electrolytes, and heat through the

\footnotetext{
*Correspondence: corcao@ufrgs.br

Department of Microbiology, Immunology and Parasitology, Institute of Basic Health Sciences, Universidade Federal do Rio Grande do Sul, Sarmento Leite 500, Porto Alegre 90050-170, Brazil
}

wound [2]. The major concern regarding the use of allogeneic skin is the risk of disease transmission by potential pathogens, as skin transplant recipients are often immunologically compromised and are consequently more susceptible to infections, (i.e., patients with severe burns) [1].

Microbial contamination is the main reason for tissue discharge in tissue banks [3]. Unlike other tissues, the skin is colonized by skin-associated microorganisms therefore it cannot be considered sterile at the time of harvesting [4]. In addition to the endogenous microbiota, contamination may also originate from the respiratory tract and bowel, or exogenously from the 
retrieval staff, mortuary [5], or hospital environment [6]. Although superficial decontamination of the donor's skin with antiseptics is performed before harvesting, the procedure is not indefectible [4]. Skin banks are therefore responsible for ensuring a safe availability of skin for grafting by performing microbiological screening before and after processing the allogeneic skin.

The skin bank of Dr. Roberto Corrêa Chem from the Hospital Complex Santa Casa de Misericórdia de Porto Alegre was founded in 2005 and was the first skin bank created in Rio Grande do Sul. It was the second skin bank in Brazil, but for a long time it was the only one in effective operation [7]. In the processing of skin allograft, the microbiological screening is at the moment of tissue obtainment. After being harvested, strips of allogenous skins are sampled by passing a sterile swab over their entire length, on both sides, and by collecting a fragment from each tip of the strips, that are then cultured in appropriate media. Only allogeneic skins that do not present microbial growth or growth of acceptable microorganisms (considered non-pathogenic) proceed to the next phase of processing. Skin samples with nonacceptable microorganisms are immediately discarded. Allogeneic skins with acceptable microorganisms are then submitted to a first cycle of treatment with penicillin and streptomycin and, if necessary, a second cycle of treatment with vancomycin. Therefore only skins with negative microbiological cultures after treatment are released for grafting. However, as in other skin banks $[3,8]$, the skin bank of Dr. Roberto Corrêa Chem faces the problem of discards due to persistent bacterial contamination.

Tissue decontamination is a challenge for tissue banks, and currently there is little consensus about the combination and concentration of antibiotics to be used, which highlights the need for more research on this subject [9, 10]. Most of the published manuscripts only identify the contaminants from skin grafts or test the different antimicrobial cocktails on skin, they do not assess the bacteria's susceptibility to the antimicrobials used or test these cocktails on nonskin bacteria.

This study aimed to perform a bacteriological analysis by identifying bacteria from human skin allografts and analyzing their antimicrobial susceptibility profile by evaluating the inhibitory potential. The inhibitory potential was calculated from the minimal inhibitory concentration (MIC) $\left(\mathrm{MIC}_{50}\right.$ and $\mathrm{MIC}_{90}$ ) of the antimicrobials already used in the skin bank and those that most isolates were susceptible to. The results should contribute to a better understanding of which factors are contributing to the persistence of bacterial contamination in skin allografts. This initial evaluation of the susceptibility profile should also provide changes in the antimicrobial cocktails used in the treatment of skin allografts.

\section{Methods \\ Ethics}

This research was approved by the Research Ethics Committees of the Universidade Federal do Rio Grande do Sul (protocol CAAE 36949514.8.0000.5347) and the Irmandade da Santa Casa de Misericordia de Porto Alegre (protocol CAAE 45100215.1.0000.5335).

\section{Skin samples}

A total of 32 batches of human skin samples procured from cadaveric donors between July 2012 to November 2014, were available from the skin bank of Dr. Roberto Corrêa Chem from the Hospital Complex Santa Casa de Misericórdia de Porto Alegre. The skin allografts were harvested from donors with encephalic death (multi-organ donors) and those who suffered cardiorespiratory arrest. The donors were only accepted after family informed consent for recovery, serology and the use of the skin for research purposes; social and medical history of the donor and physical examination. Briefly, allogeneic skin is procured in aseptic conditions, in operating room with adherence to standards and guidelines. Removal of tissues is carried out until $12 \mathrm{~h}$ after the interruption of blood circulation, if the cadaver was kept at room temperature, or up to $24 \mathrm{~h}$ if the cadaver was refrigerated at $4{ }^{\circ} \mathrm{C} \pm 2{ }^{\circ} \mathrm{C}$ within 06 (six) hours after disruption of blood circulation. The recovery areas are trunk, thighs and for male donors also the legs. Each donor is divided into two batches: batch 1 (tissue harvested from anterior sites of the body) and batch 2 (back sites of the body), being that all processing steps are performed individually for each batch. After the tricotomy of the donor areas, disinfection with chlorhexidine degermant followed by dyeing with alcoholic chlorhexidine are performed. Skin strips $5 \times 20 \mathrm{~cm}$ thick are harvested with an electric dermatome. A microbiological screening is done by culturing the swab and the tip fragments of the skin strips. Then, skin samples are placed in $50 \%$ glycerol to be transported to the skin bank to be performed the next processing procedures according to microbiological results. Microbiological analyzes are performed at all stages of the skin bank processing. If rthe considered nonacceptable microorganisms: aerobic or anaerobic Gram-negative bacilli, Gram-negative cocci, Clostridium sp., Bacillus anthracis, Streptococcus pyogenes (beta hemolytic); Staphylococcus aureus; Enterococcus sp. and filamentous fungi or yeasts, the tissue is discarded. In case of contamination by other microorganisms, the skin must undergo antibiotic treatment, first cycle with penicillin $(1000 \mathrm{U} / \mathrm{mL})$ and streptomycin $(200 \mathrm{mg} / \mathrm{mL}$ ) and second cycle of vancomycin $(50 \mathrm{mg} /$ $\mathrm{mL}$ ), if the first cycle fails. Skins free from contamination are stored in $85 \%$ glycerol and maintained at $+4 \pm 2{ }^{\circ} \mathrm{C}$ up to two years, being available for grafting. 
The 32 skin batches were harvested from 28 donors, 17 corresponding to batch 1 and 15 to batch 2 . The donors age ranged from 10 to 72 years (mean 35.56 years), 16 females and 12 males. All batches had already been discarded due to microbial contamination with nonacceptable microorganisms or to the persistence of bacterial contamination, after the first or the second cycle of treatment performed in the skin bank.

\section{Bacterial culture, isolation, and identification}

After a sterile washing step with $0.85 \%$ sodium chloride solution in a laminar air flow cabinet, $1 \mathrm{~cm}^{2}$ of each skin strip (representing the totality of the sample) was transferred to $80 \mathrm{~mL}$ of tryptone soya broth (TSB) incubated at $37{ }^{\circ} \mathrm{C}$ for $24 \mathrm{~h}$ in aerobic conditions and in $80 \mathrm{~mL}$ of thioglycolate broth (TGB) incubated at $37{ }^{\circ} \mathrm{C}$ for $48 \mathrm{~h}$ in anaerobic conditions. If no turbidity was detected within this period, the samples were maintained for up to 14 days under the conditions described above [8].

For bacterial isolation, an aliquot of the skin culture in TSB and TGB was inoculated in blood agar, mannitol salt agar, MacConkey agar, and eosin methylene blue agar in duplicate. Culture mediums inoculated from TSB were incubated in aerobiose and those inoculated from TGB were incubated in anaerobiosis, both at $37{ }^{\circ} \mathrm{C}$ for 24 and $48 \mathrm{~h}$, respectively. Five isolates with equal colony morphology were chosen from the agar plates. All isolated colonies were stored in Broth Heart Brain Infusion (BHI) with 15\% glycerol at $-20{ }^{\circ} \mathrm{C}$. For Gram-positive cocci, tube coagulase and DNase tests were performed to differentiate Staphylococcus aureus from coagulase-negative staphylococci (CNS).

Isolates were identified using matrix assisted laser desorption ionization-time of flight (MALDI-TOF) (Microflex Biotyper 4.0, Bruker) according to the manufacturer's specifications. A recent culture colony, or $1 \mu \mathrm{L}$ of supernatant from the extraction procedure, was directly spotted onto the MALDI plate. This was overlaid with $1 \mu$ l of saturated $\alpha$-cyano-4-hydroxycinnamic acid and allowed to dry. The loaded plate was placed in the instrument for reading. The spectra were analyzed using MALDI Biotyper 4.0 software by standard pattern matching with a default setting. Scores $>2$ were considered to indicate species identification, while scores of 1.70-1.99 indicated identification at the genus level. Scores under 1.70 indicated no significant similarity of the spectra with any database entry.

\section{Antibiotic susceptibility tests}

Susceptibility to the antimicrobials (Oxoid ${ }^{\mathrm{TM}}$ Disks), the benzylpenicillin penicillin G $10 \mathrm{U}(\mathrm{PEN})$, cefoxitin $30 \mu \mathrm{g}$ (CFO), ciprofloxacin $5 \mu \mathrm{g}$ (CIP), amikacin $30 \mu \mathrm{g}$ (AMI), gentamicin $10 \mu \mathrm{g}$ (GEN), tetracycline $30 \mu \mathrm{g}$ (TET), streptomycin $10 \mu \mathrm{g}$ (EST), and azithromycin $15 \mu \mathrm{g}$ (AZM) was determined using the disk-diffusion method. Colonies cultured from tryptone soya agar (TSA) were suspended in sterile saline, brought to turbidity 0.5 of the McFarland standard and streaked across Mueller Hinton agar (MHA). After 10-15 min, antimicrobial disks were placed on MHA, incubated at $35{ }^{\circ} \mathrm{C}$ for $24 \mathrm{~h}$. Inhibition halos were read following the interpretative criteria diameter zone for staphylococci [11-13], with the exception of EST where the interpretative criteria diameter zone for Enterococcus sp. was used [14]. S. aureus ATCC 29213 was used as a control.

The MIC of the antimicrobials to which the isolates were all susceptible (AMI, GEN, and TET) and those used in the skin bank (PEN, EST, and vancomycin (VAN)) was assessed by MIC gradient strips (M.I.C.Evaluators ${ }^{\mathrm{TM}}$, Oxoid). Colonies were suspended in sterile saline (turbidity equivalent to $0.5 \mathrm{McF}$ arland standard) and streaked across MHA. The strips were placed on MHA after 10$15 \mathrm{~min}$, incubated at $35^{\circ} \mathrm{C}$ for $24 \mathrm{~h}$, and read according to the manufacturer's specifications. To describe the efficacy of the antimicrobials, $\mathrm{MIC}_{50}$ (MIC value at which $\geq 50 \%$ of the isolates were inhibited) and $\mathrm{MIC}_{90}$ (MIC value at which $\geq 90 \%$ of the isolates were inhibited) values were calculated. Apart from EST, which does not have a defined breakpoint value, all MIC breakpoints were interpreted following CLSI M100-S25 [11] for Gram-positive cocci and CLSI M45-A2 [15] for Gram-positive bacilli.

\section{Results}

\section{Bacterial isolation and identification}

Of the 32 evaluated skin samples, 21 (65.6\%) were positive for bacterial culture with Gram-positive bacteria, among which two had previously been submitted to the first cycle of antimicrobial treatment and five to the first and second treatment in the skin bank. Considering the MALDI-TOF score criteria, species of Bacillus, Staphylococcus, and Paenibacillus were identified. Genera whose species were not identified were designated by sp. or by coagulase test result for Gram-positive cocci, as can be seen in Table 1. No Gram-negative bacterium was isolated from the evaluated skin samples. A total of 790 bacterial isolates were obtained, 507 (65\%) Gram-positive bacilli and 283 (35\%) Gram-positive cocci.

\section{Susceptibility profile to antimicrobials}

The antimicrobial susceptibility profile was evaluated in two isolates with equal colony morphology among those isolated from each medium, totaling in 195 Gram-positive bacilli and 124 Gram-positive cocci analyzed. All Gram-positive bacilli were susceptible to CIP, AMI, GEN, and TET, and $92(48.7 \%)$ of these were susceptible to all other antimicrobials tested (Table 2). They presented seven distinct antimicrobial resistance profiles (Table 2). Twenty-eight (14.3\%) isolates were resistant to a single 
Table 1 Identification and prevalence of bacteria isolated from human skin grafts

\begin{tabular}{ll}
\hline Isolated bacteria & $\begin{array}{l}\text { Prevalence in skin } \\
\text { samples }(n=21)\end{array}$ \\
\hline Gram-positive bacilli & $7(33.3 \%)$ \\
Bacillus cereus & $7(33.3 \%)$ \\
Bacillus subtilis & $7(33.3 \%)$ \\
Bacillus sp. & $3(14.2 \%)$ \\
Bacillus vallismortis & $1(4.7 \%)$ \\
Bacillus pumilus & $1(4.7 \%)$ \\
Bacillus licheniformis & $1(4.7 \%)$ \\
Paenibacillus sp. & \\
Gram-positive cocci & $4(19 \%)$ \\
Staphylococcus epidermidis & $2(9.5 \%)$ \\
Staphylococcus aureus & $1(4.7 \%)$ \\
Staphylococcus capitis & $1(4.7 \%)$ \\
Staphylococcus saprophyticus & $1(4.7 \%)$ \\
Staphylococcus lugdunensis & $1(4.7 \%)$ \\
Staphylococcus haemolyticus & $1(4.7 \%)$ \\
Coagulase-negative staphylococci &
\end{tabular}

antimicrobial, 64 (51.6\%) were resistant to two antimicrobials, and 11 (5.6\%) were resistant to three antimicrobials. The PEN-CFO resistance profile was the most prevalent, being found in all Bacillus cereus. A total of 11 (5.6\%) isolates, including B. cereus and Paenibacillus sp., were resistant to three different classes of antimicrobials and were therefore classified as multidrug resistant (MDR) [16].

Among the 102 (52\%) PEN- and EST-resistant bacilli isolates, 59 were isolated from skin samples submitted to the first and second treatment cycles with these antimicrobials and 49 (83\%) were susceptible to at least one of them. Another 10 bacilli from treated skin samples were susceptible to both of them (Table 2).

All of the 124 Gram-positive cocci analyzed were susceptible to AMI, GEN, and TET and 19 (15.3\%) were susceptible to all other antimicrobials tested (Table 2). Eight antimicrobial resistance profiles were observed, of which PEN-CFO-CIP-AZM was the most prevalent being observed in 54 (43.5\%) Gram-positive cocci. A total of $60(48.3 \%)$ isolates were classified as MDR, being resistant to three or more different classes of antimicrobials, including S. aureus, S. saprophyticus, S. epidermidis, and S. capitis. In addition, 61 (49.1\%) staphylococci isolates were oxacillin-resistant based on CFO results predicting methicillin resistance (Table 2).

A total of $84(67.7 \%)$ Gram-positive cocci were resistant to PEN and no coccus isolates showed resistance to

Table 2 Susceptibility profile of Gram-positive bacilli and Gram-positive cocci isolated from human skin allografts with and without antimicrobial treatment

\begin{tabular}{|c|c|c|c|c|c|c|c|c|c|c|c|}
\hline \multicolumn{6}{|l|}{ Gram-Positive Bacilli } & \multicolumn{6}{|l|}{ Gram-Positive Cocci } \\
\hline \multirow{2}{*}{$\begin{array}{l}\text { Antimicrobial } \\
\text { resistance profile }\end{array}$} & \multirow{2}{*}{$\begin{array}{l}\text { Number of } \\
\text { isolates } \\
(n=195)\end{array}$} & \multirow[t]{2}{*}{ Isolates } & \multicolumn{3}{|c|}{ Treatment } & \multirow{2}{*}{$\begin{array}{l}\text { Antimicrobial } \\
\text { resistance profile }\end{array}$} & \multirow{2}{*}{$\begin{array}{l}\text { Number of } \\
\text { isolates } \\
(n=124)\end{array}$} & \multirow[t]{2}{*}{ Isolates } & \multicolumn{3}{|c|}{ Treatment } \\
\hline & & & WT & $1 \mathrm{ST}$ & $1 \mathrm{ST} / 2 \mathrm{ND}$ & & & & $\overline{W T}$ & 1ST & $1 \mathrm{ST} / 2 \mathrm{ND}$ \\
\hline $\begin{array}{l}\text { PEN } \\
\text { CFO }\end{array}$ & $\begin{array}{l}27 \\
1\end{array}$ & $\begin{array}{l}\text { B. cereus } \\
\text { B. subtilis } \\
\text { B. licheniformis } \\
\text { Bacillus sp. } \\
\text { B. vallismortis }\end{array}$ & $\begin{array}{l}2 \\
1 \\
9 \\
3 \\
1\end{array}$ & $\begin{array}{l}- \\
- \\
-\end{array}$ & $\begin{array}{l}12 \\
- \\
- \\
-\end{array}$ & $\begin{array}{l}\text { PEN } \\
\text { CFO } \\
\text { AZM }\end{array}$ & $\begin{array}{l}20 \\
1 \\
13\end{array}$ & $\begin{array}{l}\text { S. aureus } \\
\text { S. lugdunensis } \\
\text { CNS } \\
\text { S. haemolyticus } \\
\text { CNS }\end{array}$ & $\begin{array}{l}19 \\
1 \\
12 \\
-\end{array}$ & $\begin{array}{l}- \\
\frac{1}{1} \\
1\end{array}$ & $\begin{array}{l}- \\
- \\
- \\
-\end{array}$ \\
\hline $\begin{array}{l}\text { PEN-CFO } \\
\text { CFO-EST } \\
\text { PEN-AZM }\end{array}$ & $\begin{array}{l}59 \\
4 \\
1\end{array}$ & $\begin{array}{l}\text { B. cereus } \\
\text { Paenibacillus sp. } \\
\text { B. cereus }\end{array}$ & $\begin{array}{l}28 \\
- \\
-\end{array}$ & $\begin{array}{l}2 \\
4 \\
-\end{array}$ & $\frac{29}{1}$ & $\begin{array}{l}\text { PEN-CIP } \\
\text { PEN-AZM } \\
\text { CIP-AZM }\end{array}$ & $\begin{array}{l}9 \\
1 \\
1\end{array}$ & $\begin{array}{l}\text { S. aureus } \\
\text { S. epidermidis } \\
\text { S. epidermidis } \\
\text { S. epidermidis }\end{array}$ & $\begin{array}{l}5 \\
4 \\
1 \\
1\end{array}$ & $\begin{array}{l}- \\
- \\
-\end{array}$ & $\begin{array}{l}- \\
- \\
-\end{array}$ \\
\hline $\begin{array}{l}\text { PEN-CFO-EST } \\
\text { PEN-CFO-AZM }\end{array}$ & $\begin{array}{l}10 \\
1\end{array}$ & $\begin{array}{l}\text { B. cereus } \\
\text { Paenibacillus sp. } \\
\text { B. cereus }\end{array}$ & $\begin{array}{l}- \\
-\end{array}$ & $\begin{array}{l}- \\
-\end{array}$ & $\frac{8}{1}$ & $\begin{array}{l}\text { CFO-CIP-AZM } \\
\text { PEN-CFO-CIP-AZM }\end{array}$ & 54 & $\begin{array}{l}\text { S. epidermidis } \\
\text { S. saprophyticus } \\
\text { S. epidermidis } \\
\text { S. capitis } \\
\text { S. saprophyticus } \\
\text { S. aureus }\end{array}$ & $\begin{array}{l}5 \\
1 \\
35 \\
17 \\
1 \\
1\end{array}$ & $\begin{array}{l}- \\
- \\
- \\
-\end{array}$ & $\begin{array}{l}- \\
- \\
- \\
-\end{array}$ \\
\hline Susceptible to all ATM & 92 & $\begin{array}{l}\text { Bacillus sp. } \\
\text { B. subtilis } \\
\text { B. vallismortis } \\
\text { B. pumilus } \\
\text { B. licheniformis } \\
\text { B. cereus }\end{array}$ & $\begin{array}{l}49 \\
25 \\
4 \\
2 \\
1 \\
1\end{array}$ & $\begin{array}{l}2 \\
- \\
- \\
-\end{array}$ & $\begin{array}{l}4 \\
4 \\
- \\
- \\
-\end{array}$ & Susceptible to all ATM & 19 & $\begin{array}{l}\text { S. haemolyticus } \\
\text { S. lugdunensis }\end{array}$ & $\begin{array}{l}4 \\
15\end{array}$ & - & - \\
\hline
\end{tabular}

1ST, isolates obtained from skin samples previously submitted to the first cycle of treatment with penicillin and streptomycin in the skin bank; $2 N D$, isolates obtained from skin samples previously submitted to the second cycle of treatment with vancomycin; ATM, antimicrobials; AZM, azithromycin; CFO, cefoxitin; CIP, ciprofloxacin; CNS, coagulase-negative staphylococci; EST, streptomycin; PEN, penicillin; WT, without treatment 
EST. The two CNS isolated from skin samples submitted to the first treatment in the skin bank were susceptible to both PEN and EST (Table 2).

\section{Antimicrobial inhibitory potential}

The inhibitory potential of the antimicrobials to which all isolates were susceptible by disk-diffusion method (AMI, GEN, and TET) and those used in the skin bank (PEN, EST, and VAN) were evaluated against the isolated bacteria to assess their efficiency (Table 3). For this purpose, 103 Gram-positive cocci and 118 Gram-positive bacilli with different susceptibility profiles were chosen and analyzed using MIC gradient strips.

For Gram-positive bacilli PEN $\mathrm{MIC}_{50}$ was $1 \mu \mathrm{g} / \mathrm{mL}$ and for Gram-positive cocci PEN $\mathrm{MIC}_{50}$ was $8 \mu \mathrm{g} / \mathrm{mL}$, and both presented PEN $\mathrm{MIC}_{90}$ values of $>32 \mu \mathrm{g} / \mathrm{mL}$. EST $\mathrm{MIC}_{50}$ was $2 \mu \mathrm{g} / \mathrm{mL}$ and EST $\mathrm{MIC}_{90}$ was $32 \mu \mathrm{g} / \mathrm{mL}$ for Gram-positive bacilli while for Gram-positive cocci EST $\mathrm{MIC}_{50}$ and $\mathrm{MIC}_{90}$ was $4 \mu \mathrm{g} / \mathrm{mL}$ and $8 \mu \mathrm{g} / \mathrm{mL}$, respectively. VAN $\mathrm{MIC}_{50}$ was $2 \mu \mathrm{g} / \mathrm{mL}$ for Gram-positive bacilli and cocci, and VAN $\mathrm{MIC}_{90}$ was $8 \mu \mathrm{g} / \mathrm{mL}$ for Gram-positive bacilli and $2 \mu \mathrm{g} / \mathrm{mL}$ for Gram-positive cocci. AMI MIC 50 of $0.5 \mu \mathrm{g} / \mathrm{mL}$ and $\mathrm{MIC}_{90}$ of $1 \mu \mathrm{g} / \mathrm{mL}$ was showed by Gram-positive bacilli while for Gram-positive cocci was AMI $\mathrm{MIC}_{50}$ of $2 \mu \mathrm{g} / \mathrm{mL}$ and $\mathrm{MIC}_{90}$ of $4 \mu \mathrm{g} / \mathrm{mL}$. GEN $\mathrm{MIC}_{50}$ of $0.5 \mu \mathrm{g} / \mathrm{mL}$ and $\mathrm{MIC}_{90}$ of $2 \mu \mathrm{g} / \mathrm{mL}$ was observed for both Gram-positive bacilli and cocci. TET $\mathrm{MIC}_{50}$ was $0.5 \mu \mathrm{g} / \mathrm{mL}$ and $\mathrm{MIC}_{90}$ was $8 \mu \mathrm{g} / \mathrm{mL}$ for Gram-positive bacilli. For Gram-positive cocci TET $\mathrm{MIC}_{50}$ was $1 \mu \mathrm{g} / \mathrm{mL}$ and $\mathrm{MIC}_{90}$ was $2 \mu \mathrm{g} / \mathrm{mL}$ (Table 3).

Considering all the 221 Gram-positive bacilli and cocci avaluated, for elimination of $90 \%$ of them was observed MIC values of $>32 \mu \mathrm{g} / \mathrm{mL}$ for PEN, $16 \mu \mathrm{g} / \mathrm{mL}$ for EST, $8 \mu \mathrm{g} / \mathrm{mL}$ for VAN, $2 \mu \mathrm{g} / \mathrm{mL}$ for AMI and GEN, and $4 \mu \mathrm{g} / \mathrm{mL}$ for TET. Therefore,

AMI and GEN presented the highest inhibitory activity, followed by TET. Both AMI, GEN and TET presented $\mathrm{MIC}_{90}$ values less than the susceptibility breakpoints established by CLSI M45-A2 [15] and CLSI M100-S25 [11], respectively, for Bacillus sp. and Staphylococcus sp., with exception TET $\mathrm{MIC}_{90}$ that was equal to the intermediate resistance breakpoint for Bacillus sp., indicating the absence of resistance to these antimicrobials. Meanwhile, PEN, EST, and VAN were the least active, requiring higher concentrations to inhibit the growth of the isolates. $\mathrm{PEN} \mathrm{MIC}_{90}$ was 128 -fold higher than the breakpoint of resistance $(\geq 0.25 \mu \mathrm{g} / \mathrm{mL}$, CLSI M45-A2 [15], CLSI M100-S25 [11]) for Bacillus sp. and Staphylococcus sp., demonstrating high PEN resistance among the isolates. VAN $\mathrm{MIC}_{90}$ was two-fold higher than the breakpoint of susceptibility $(\leq 4 \mu \mathrm{g} / \mathrm{mL}$, CLSI M45-A2 [15]) for Bacillus sp., suggesting that some bacilli isolates were nonsuceptible to VAN. Moreover VAN MIC 90 presented equal value of the breakpoint of intermediate resistance for Staphylococcus sp. (Table 3).

Regarding the bacteria isolated from skin samples previously submitted to the first treatment with PEN in the skin bank, individual MIC analysis revealed that 43 (93.4\%) of the 46 Gram-positive bacilli were PEN resistant, presenting PEN MIC values between 0.25 and $\geq 32 \mu \mathrm{g} / \mathrm{mL}$. Three of the isolates (6.5\%) were susceptible to PEN with MIC values between 0.03 and $0.06 \mu \mathrm{g} / \mathrm{mL}$. Two of the Gram-positive cocci were susceptible to PEN with MIC values of between 0,06 and $0,12 \mu \mathrm{g} / \mathrm{mL}$ (Additional file 1).

Of the 39 Gram-positive bacilli submitted to the second cycle of treatment with VAN, 18 (46.1\%) were shown to be susceptible and presented MIC values between 0.25 and $2 \mu \mathrm{g} / \mathrm{mL}$. However, 21 (53.8\%) Gram-positive bacilli were resistant to VAN, showing MIC values between 8 and $16 \mu \mathrm{g} / \mathrm{mL}$ (Additional file 1). No skin sample, which was submitted to the second cycle of treatment with VAN, presented Gram-positive cocci.

\section{Discussion}

The primary aim of this study was to analyze the bacterial contaminants of allogeneic skin samples from the skin bank of Dr. Roberto Corrêa Chem from the Hospital Complex Santa Casa de Misericórdia de Porto Alegre. $\mathrm{Ba}$ cillus sp., Staphylococcus sp., and Paenibacillus sp. were identified. The most prevalent Gram-positive bacilli was B. cereus and the most prevalent Gram-positive cocci was S. epidermidis.

Table $3 \mathrm{MIC}_{50}$ and $\mathrm{MIC}_{90}$ values of penicillin, streptomycin, vancomycin, amikacin, gentamicin, and tetracycline for Gram-positive bacilli and cocci

\begin{tabular}{|c|c|c|c|c|c|c|c|}
\hline Isolates & $\mu \mathrm{g} / \mathrm{mL}$ & PEN & EST & VAN & AMl & GEN & TET \\
\hline \multirow[t]{2}{*}{ Gram-positive bacilli $(n=118)$} & $\mathrm{MIC}_{50}$ & 1 & 2 & 2 & 0.5 & 0.5 & 0.5 \\
\hline & $\mathrm{MIC}_{90}$ & $>32$ & 32 & 8 & 1 & 2 & 8 \\
\hline \multirow[t]{2}{*}{ Gram-positive cocci $(n=103)$} & $\mathrm{MIC}_{50}$ & 8 & 4 & 2 & 2 & 0.5 & 1 \\
\hline & $\mathrm{MIC}_{90}$ & $>32$ & 8 & 4 & 4 & 2 & 2 \\
\hline \multirow[t]{2}{*}{ Gram-positive bacilli and cocci $(n=221)$} & $\mathrm{MIC}_{50}$ & 8 & 4 & 2 & 0.5 & 0.5 & 1 \\
\hline & $\mathrm{MIC}_{90}$ & $>32$ & 16 & 8 & 2 & 2 & 4 \\
\hline
\end{tabular}

$A M I$, amikacin; $E S T$, streptomycin; $G E N$, gentamicin; $M I C_{50}$, MIC value at which $\geq 50 \%$ of the isolates were inhibited; $M I C_{90}$, MIC value at which $\geq 90 \%$ of the isolates were inhibited $P E N$, penicillin; TET, tetracycline; $V A N$, vancomycin 
Another Brazilian skin bank has also reported skin contamination by Gram-positive bacteria, including CNS (42\%), Gram-positive bacilli (not Clostridium) (18\%), coagulase-positive staphylococci (10\%), and Enterococcus sp. (7\%) [17]. Lindford et al. [18] found that Staphylococcus and Bacillus were the most prevalent bacteria in skin allografts. Other authors $[1,3,8]$ have identified CNS, especially S. epidermidis, as the most common bacteria in skin allografts. However, other studies have also detected Gram-negative bacteria such as Escherichia coli, Klebsiella pneumoniae, Pseudomonas aeruginosa, Proteus sp., Acinetobacter baumannii, and Enterobacter cloacae $[1,3,8,18]$. The absence of Gram-negative bacilli in the present work may be due to the fact that the analyzed skin samples were immersed in $85 \%$ glycerol for long periods of time, the inhibitory action of which is more potent in Gram-negative bacteria. The higher susceptibility of Gram-negative bacteria to high glycerol concentrations is due to the thin layer of peptidoglycan, which constitutes only $10 \%$ of the cell wall. Conversely, the peptidoglycan content in Gram-positive bacteria corresponds to $90 \%$ of the cell wall and is therefore more resistant to osmotic lysis [19]. Studies have also shown that glycerol is unable to sterilize skin as it cannot eliminate bacterial spores $[4,19]$.

Bacillus sp. and Paenibacillus sp. are noteworthy as they form spores that are resistant to heat, cold, and common disinfectants, which allows them to survive on surfaces for prolonged periods [20]; Bacillus sp. have been found even on the skin surface of healthy individuals [21]. There are few methods that reduce skin spore levels in a clinical setting, mainly in hospitalized patients [22]. Bacillus sp. and Paenibacillus sp. have been isolated in these individuals [23]. In addition to forming spores, these bacteria seem to be sufficiently equipped with virulence properties that allow them to behave as pathogens and opportunistic pathogens in humans [23].

Among the Staphylococcus species, S. epidermidis, S. haemolyticus, S. capitis, and S. lugdunensis can be considered to be an integral part of the normal skin microbiota. However, although less virulent, these coagulase-negative species may cause infections [24]. They are particularly associated with infections caused by the use of implanted devices and they have a high capacity for biofilm formation, which shows significant resistance to antibiotics [25].

Several species detected in this study (i.e., Paenibacillus sp. [26], B. cereus [27], B. subtilis [28], B. pumilus [29], B. licheniformis [30], S. aureus [31], S. epidermidis [24], and S. capitis [32]) have already been shown to directly cause infections in the skin, open-wounds, or the blood (via skin lesions). With the exception of $S$. aureus and B. cereus, most of the bacteria isolated in this study are considered to be of low pathogenicity [3], including normal human skin microbiota and common environmental organisms.
However, they should not be underestimated as they are isolated from skin grafts that are usually transplanted into immunocompromised individuals with a high risk of acquiring a serious opportunistic infection [18].

Few articles discuss about susceptible profiles to antimicrobials of bacteria isolated from skin allografts. This is an important tool to guide the choice of an appropriate antibiotic treatment, especially if the applied treatments are not completely efficient. Among the 319 isolates that had their susceptible profiles determined, 71 (22.2\%) were multidrug resistant. This is not the first time that MDR bacteria have been reported in tissue bank samples [33]. Pianigiani et al. [34] found MDR Staphylococci isolated from skin allografts, that called for treatment with vancomycin on the basis of antibiograms.

Regarding the MIC values, it was observed high levels of resistance to PEN in a portion of the population of the isolates evaluated, in addition to nonsuceptible isolates and intermediate resistant to VAN. In view of this, the resistance to the antimicrobials applied in the decontamination treatment of the skin allografts might be contributing to its inefficiency.

The inhibitory potential of the antimicrobials used in the skin bank showed to be less effective, requiring high concentrations to kill the isolates evaluated. Considering all the 221 isolates of bacilli and cocci, PEN showed MIC90 values higher than their breakpoint of resistance. VAN MIC90 presented equal value of the breakpoint of intermediate resistance for Staphylococcus sp. and nonsuceptible breakpoint for Bacillus sp. (including Paenibacillus sp.). Streptomycin did not have reference values, but among the antimicrobials used in the skin bank, presented the second highest value of MIC90 $(16 \mu \mathrm{g} / \mathrm{mL})$. Interestingly the MIC values of these three antimicrobials were much lower than the concentrations used in the skin bank, which concentrations might have eliminated at least the bacteria susceptible to them. It is possible that such concentrations were quite ineffective against susceptible bacteria due to the 'Eagle effect', where antibiotics, particularly $\beta$-lactams, exhibits reduced potential killing at high drug concentrations $[9,35]$. AMI, GEN and TET presented MIC90 values less than the susceptibility breakpoints established for the isolates, being much more effective at lower concentrations than the antimicrobial concentrations already used in the skin bank.

These findings highlights the need to find different alternatives of antimicrobial treatments and a monitoring of resistance within the tissue banks, since broad spectrum antimicrobials are used and can select resistant bacteria, making it even more difficult to eliminate contamination from tissue allografts. In addition, the concentration of antimicrobials should also be better studied, so that an ideal value is reached, which eliminates the greater amount of bacteria found in the skin 
allografts, without selecting resistant strains [36] nor a high concentration that loses its effect [35].

Little information is available regarding the treatment of infections caused by Bacillus or Paenibacillus strains [23]. B. cereus are described as potent producers of broad-spectrum $\beta$-lactamases, which affect penicillins and cephalosporins [15]. This may explain their high levels of resistance to PEN, CAZ, and CFO. B. cereus is known to be susceptible to aminoglycosides, chloramphenicol, clindamycin, erythromycin, TET, and VAN [37], therefore of the antimicrobials tested in this study, AMI, GEN, and TET may be efficient at eliminating vegetative forms of Bacillus species.

Methicillin-resistant staphylococci (MRS) is considered to be resistant to all currently-available $\beta$-lactam antimicrobial agents except for cephalosporins, which have anti-methicillin-resistant Staphylococcus aureus (anti-MRSA) activity [11]. Thus the elaboration of a new treatment cocktail should take this into consideration.

Previous studies have already shown that antibiotic resistance has increased in skin isolates, which may reflect the indiscriminate use of antibiotics over the last few years [21]. Cosmetic products containing antibiotics and disinfectants may also be associated with this resistance [38]. Hospital environments such as intensive care are populated by antibiotic-resistant species [34] and considering that some skin donors might have previously undergone hospitalization, the characteristics of their microbiota may have been modified by the bacteria present in this environment, both in terms of their composition [3, 6] as their resistance to antimicrobials [39].

Although some isolates presented a MDR profile, most of the isolates submitted to the first treatment with PEN and EST were susceptible to one or both of these antimicrobials. This suggests that other factors that are unrelated to antimicrobial resistance may be contributing to the persistence of these bacteria in skin allografts. The inefficiency of EST to eliminate bacteria may be due to the fact that aminoglycosides are indicated in combination with other active agents, (i.e., $\beta$-lactam) [11]. This may explain why EST alone was not able to eliminate PEN-resistant staphylococci isolates.

Pirnay et al. [8] tested a cocktail (TM1) containing penicillin, EST, and amphotericin B and observed that it failed to decontaminate $47.4 \%$ of skin grafts tested. Of the seven skin samples that were treated with PEN and EST in this study, the contamination was also shown to persisted. Pirnay et al. also tested a second cocktail (TM2) composed of GEN sulfate, imipenem/cilastin, polymyxin B sulfate, $\mathrm{VAN} \mathrm{HCl}$, and nystatin and found that it was also unable to decontaminate the skin samples. Disk-diffusion analysis demonstrated that bacteria from samples treated with TM2 were susceptible to at least one of the antibiotics present in the cocktail, as has been observed in this study. Gaucher el al. [3] also reported the persistence of VAN-susceptible bacteria even after skin allografts were treated with a cocktail containing high concentration of this antimicrobial.

Some reasons may cause antimicrobial skin decontamination to be inefficient even if the bacteria are susceptible to them. For example, spore-forming bacteria can remain dormant for long periods and are extremely resistant to the action of antimicrobials [40]. Bacteria may also remain within pores or hair follicles and thus evade the action of antimicrobials that cannot reach such sites [41]. Some bacteria may also form biofilms on the skin [42]. Some studies have already reported biofilm formation in other types of grafts, such as bone [43] and prosthetic vascular grafts [44].

The organization of bacterial cells into a biofilm may cause them to be more tolerant to the effects of antimicrobial agents; even bacteria that do not have a genetic basis for antimicrobial resistance may reduce their susceptibility when they form biofilms [45]. It is important to highlight that most of the antimicrobials used in the clinic only target cells in the planktonic state. Furthermore, some antimicrobial agents may stimulate the production of biofilms by certain microorganisms [46]. For the treatment of allogeneic skin grafts it may therefore be necessary to incorporate not only antibiotics but also other compounds that interfere with other functions of bacterial cells (i.e., biofilm destabilization or spore elimination).

In this study, all Gram-positive cocci and bacilli were susceptible to AMI, GEN, and TET. Therefore one or more of these antimicrobials could be included into a skin treatment cocktail. Adjustments in the concentrations of antimicrobials already used in the skin bank, or combinations of antimicrobials of different classes, may be more efficient in the process of skin allograft decontamination. Some studies have already tested GEN and AMI in different cocktails for the treatment of skin allografts $[6,47]$; however, TET has not yet been tested. This should encourage future studies to combine the antimicrobials with the best inhibitory potential.

\section{Conclusions}

This is the first article to describe a microbiological screening and antimicrobial susceptible profile for bacteria isolated from human skin allografts in a Brazilian skin bank. Bacillus, Paenibacillus, and Staphylococcus were isolated thus demonstrating the predominance of Gram-positive bacteria contamination. Although several isolates presented multiresistance profiles, the persistence of the contamination in the majority of samples was not related to the antimicrobial resistance phenotype. This suggests that other factors may be responsible for the persistence of these bacteria in allogeneic skin. Biofilm formation is one such factor and should be studied further, especially considering that its presence in 
skin allografts could have a direct influence on the treatment method.

All isolates were susceptible to GEN, AMI, and TET and these antimicrobials showed the best inhibitory potential. Therefore these could be considered as an option for a more effective treatment cocktail.

It is important to share the results of this study to compare and discuss methodologies and findings among different tissue banks. This will help to reduce the rate of discards due to microbial contamination, increase the supply of suitable allogeneic skin, and guarantee greater safety to skin allografts recipients.

\section{Additional file}

Additional file 1: Table S1. Susceptibility profile and antimicrobial MIC values of Gram-positive bacilli isolated from human skin allografts with and without antimicrobial treatment. Table S2. Susceptibility profile and antimicrobial MIC values of Gram-positive cocci isolated from human skin allografts with and without antimicrobial treatment. (PDF $478 \mathrm{~kb}$ )

\section{Abbreviations}

AMI: Amikacin; ATM: Antimicrobials; AZM: Azithromycin; BHI: Broth heart brain infusion; CFO: Cefoxitin; CIP: Ciprofloxacin; CNS: Coagulase-negative staphylococci; EST: Streptomycin; GEN: Gentamicin; MALDI-TOF: Matrix assisted laser desorption ionization-time of flight; MDR: Multidrug resistant; MHA: Mueller Hinton agar; MIC: Minimal inhibitory concentration; PEN: Penicillin; TET: Tetracycline; TGB: Thioglycolate broth; TSA: Tryptone soya agar; TSB: Tryptone soya broth; VAN: Vancomycin; WT: Without treatment

\section{Acknowledgements}

We would like to thank Aline Francielle Damo Souza and Luana Pretto from the skin bank of Dr. Roberto Corrêa Chem from the Hospital Complex Santa Casa de Misericórdia de Porto Alegre for preparing the skin allografts samples for this study.

\section{Funding}

This study received a grant from the Conselho Nacional de Desenvolvimento Científico e Tecnológico (CNPq).

\section{Availability of data and materials}

All data and materials generated during the current study are available from the corresponding author on reasonable request.

\section{Authors' contributions}

KLM, GC, and MPG designed the experiments; KLM, MC, LMO, and TSH performed the experiments; KLM, GC, and MPG analyzed the data and wrote the manuscript; All authors read and approved the final manuscript.

\section{Ethics approval and consent to participate}

This research has been approved by the Research Ethics Committees of the Universidade Federal do Rio Grande do Sul (protocol CAAE 36949514.8.0000.5347) and the Irmandade da Santa Casa de Misericordia de Porto Alegre (protocol CAAE 45100215.1.0000.5335).

\section{Consent for publication}

Not applicable.

\section{Competing interests}

The authors declare that they have no competing interests.

\section{Publisher's Note}

Springer Nature remains neutral with regard to jurisdictional claims in published maps and institutional affiliations.
Received: 28 November 2017 Accepted: 17 September 2018

Published online: 24 September 2018

\section{References}

1. Pianigiani E, Risulo M, lerardi F, Sbano P, Andreassi L, Fimiani M, et al. Prevalence of skin allograft discards as a result of serological and molecular microbiological screening in a regional skin bank in Italy. Burns. 2006;32: 348-51.

2. Britton-Byrd BW, Lynch JP, Williamson S, McCauley RL. Early use of allograft skin: are 3-day microbiologic cultures safe? J Trauma. 2008;64:816-8.

3. Gaucher S, Khaznadar Z, Gourevitch JC, Jarraya M. Skin donors and human skin allografts: evaluation of an 11-year practice and discard in a referral tissue bank. Cell Tissue Bank. 2016;17:11-9.

4. Verbeken G, Verween G, De Vos D, Pascual B, De Corte P, Richters C, et al. Glycerol treatment as recovery procedure for cryopreserved human skin allografts positive for bacteria and fungi. Cell Tissue Bank. 2012;13:1-7.

5. Eastlund T. Bacterial infection transmitted by human tissue allograft transplantation. Cell Tissue Bank. 2006;7:147-66.

6. Mathur M, De A, Gore M. Microbiological assessment of cadaver skin grafts received in a skin bank. Burns. 2009:35:104-6.

7. Silveira DPM, Rech DL, Neto ASP, Martins ALM, Ely PB, Chem EM. Banco de Pele de Porto Alegre: produtividade e perfil dos doadores. Rev Bras Cir Plást. 2013;28:1-103.

8. Pirnay JP, Verween G, Pascual B, Verbeken G, De Corte P, Rose T, et al. Evaluation of a microbiological screening and acceptance procedure for cryopreserved skin allografts based on 14-day cultures. Cell Tissue Bank. 2012;13:287-95.

9. Pitt TL, Tidey K, Roy A, Ancliff S, Lomas R, McDonald CP. Activity of four antimicrobial cocktails for tissue allograft decontamination against bacteria and Candida spp. of known susceptibility at different temperatures. Cell Tissue Bank. 2014;15:119-25.

10. Johnston C, Callum J, Mohr J, Duong A, Garibaldi A, Simunovic N, et al. Disinfection of human skin allografts in tissue banking: a systematic review report. Cell Tissue Bank. 2016;17:585-92.

11. Clinical and Laboratory Standards Institute (CLSI). Performance Standards for Antimicrobial Susceptibility Testing. Twenty-Fifth Informational Supplement M100-S25. Wayne, PA, United States, 2015.

12. Habrun B, Racic I, Kompes G, Spicic S, Benic M, Mihaljevic Z, Cvetnic Z. The antimicrobial susceptibility and virulence factors of Bacillus anthracis strains isolated in Croatia. Vet Med. 2011;56(Suppl 1):22-7.

13. Owusu-Kwarteng J, Wuni A, Akabanda F, Tano-Debrah K, Jespersen L. Prevalence, virulence factor genes and antibiotic resistance of Bacillus cereus sensu lato isolated from dairy farms and traditional dairy products. BMC Microbiol. 2017;17:65.

14. The European Committee on Antimicrobial Susceptibility Testing. Breakpoint tables for interpretation of MICs and zone diameters, version 7.1, 2017. http://www.eucast.org/fileadmin/src/media/PDFs/EUCAST_files/ Breakpoint_tables/v_7.1_Breakpoint_Tables.pdf. Accessed 10 May 2017.

15. Clinical and Laboratory Standards Institute (CLSI). Methods for Antimicrobial Dilution and Disk Susceptibility Testing of Infrequently Isolated or Fastidious Bacteria. Approved Guidelines: Second Edition M45-A2. Wayne, PA, United States, 2010

16. Magiorakos AP, Srinivasan A, Carey RB, Carmeli Y, Falagas ME, Giske CG, et al. Multidrug-resistant, extensively drug-resistant and pandrug-resistant bacteria: an international expert proposal for interim standard definitions for acquired resistance. Clin Microbiol Infect. 2012;18:268-81.

17. Matioski AR, Silva CR, Silva-Cunha DR, Calomeno LH, Bonato FT, Nigro MA. First-year experience of a new skin bank in Brazil. Plast Aesthet Res. 2015;2: 326-31.

18. Lindford AJ, Frey I, Vuola J, Koljonen V. Evolving practice of the Helsinki skin Bank. Int Wound J. 2010;7:277-81.

19. Saegeman VS, Ectors NL, Lismont D, Verduyckt B, Verhaegen J. Short- and long-term bacterial inhibiting effect of high concentrations of glycerol used in the preservation of skin allografts. Burns. 2008;34:205-11.

20. Brown KL. Control of bacterial spores. Br Med Bull. 2000;56:158-71.

21. Tarale P, Gawande S, Jambhulkar V. Antibiotic susceptibility profile of bacilli isolated from the skin of healthy humans. Braz J Microbiol. 2015;46:1111-8.

22. Nerandzic MM, Rackaityte E, Jury LA, Eckart K, Donskey CJ. Novel strategies for enhanced removal of persistent Bacillus anthracis surrogates and Clostridium difficile spores from skin. PLoS One. 2013;8:e68706. 
23. Celandroni F, Salvetti S, Gueye SA, Mazzantini D, Lupetti A, Senesi S, et al. Identification and pathogenic potential of clinical Bacillus and Paenibacillus isolates. PLoS One. 2016;e0152831:11.

24. Von Eiff C, Arciola CR, Montanaro L, Becker K, Campoccia D. Emerging Staphylococcus species as new pathogens in implant infections. Int I Artif Organs 2006;29:360-367.

25. Becker K, Heilmann C, Peters G. Coagulase-negative staphylococci. Clin Microbiol Rev. 2014;27:870-926.

26. Ferrand J, Hadou T, Selton-Suty C, Goehringer F, Sadoul N, Alauzet C, et al. Cardiac device-related endocarditis caused by Paenibacillus glucanolyticus. J Clin Microbiol. 2013;51:3439-42.

27. Tatu AL, Ionescu MA, Clatici VG, Cristea VC. Bacillus cereus strain isolated from Demodex folliculorum in patients with topical steroid-induced rosaceiform facial dermatitis. An Bras Dermatol. 2016;91:676-8.

28. Saleh F, Kheirandish F, Azizi H, Azizi M. Molecular diagnosis and characterization of Bacillus subtilis isolated from burn wound in Iran. Res Mol Med. 2014;2:40-4.

29. Bentur HN, Dalzell AM, Riordan FA. Central venous catheter infection with Bacillus pumilus in an immunocompetent child: a case report. Ann Clin Microbiol Antimicrob. 2007:6:12.

30. Yuste JR, Franco SE, Sanders C, Cruz S, Fernández-Rivero ME, Mora G. Bacillus licheniformis as a cause of a deep skin abscess in a 5-year-old girl: an exceptional case following a plant thorn injury. J Microbiol Immunol Infect. 2016;49:819-21.

31. Lacey KA, Geoghegan JA, McLoughlin RM. The role of Staphylococcus aureus virulence factors in skin infection and their potential as vaccine antigens. Pathogens. 2016;5:22.

32. Petti CA, Simmon KE, Miro JM, Hoen B, Marco F, Chu VH, et al. Genotypic diversity of coagulase-negative staphylococci causing endocarditis: a global perspective. J Clin Microbiol. 2008:46:1780-4.

33. Atique FB, Khalil MM. The bacterial contamination of allogeneic bone and emergence of multidrug-resistant bacteria in tissue bank. Biomed Res Int. 2014:430581.

34. Pianigiani E, lerardi F, Cuciti C, Brignali S, Oggioni M, Fimiani M. Processing efficacy in relation to microbial contamination of skin allografts from 723 donors. Burns. 2010;36:347-51.

35. Eagle H, Musselman AD. The rate of bactericidal action of penicillin in vitro as a function of its concentration, and its paradoxically reduced activity at high concentrations against certain organisms. J Exp Med. 1948;88:99-131.

36. Henderson-Begg SK, Livermore DM, Hall LMC. Effect of subinhibitory concentrations of antibiotics on mutation frequency in Streptococcus pneumoniae. J Antimicrob Chemother. 2006;57:849-54.

37. Logan N, Turnbull PCB. Bacillus and other aerobic endosporeforming bacteria. In: Murray PR, Baron EJ, Jorgensen JH, et al., editors. Manual of clinical microbiology. 8th ed. Washington, DC: American Society for Microbiology; 2003. p. 445-60.

38. Horner C, Mawer D, Wilcox M. Reduced susceptibility to chlorhexidine in staphylococci: is it increasing and does it matter? J Antimicrob Chemother. 2012;67:2547-59.

39. Kwaszewska AK, Sobis-Glinkowska M, Szewczyk EM. Influence of contact with hospital environment on sensitivity to antibiotics of lipophilic strains of Conynebacterium residing on human skin. Med Dosw Mikrobiol. 2009;61:359-66.

40. Grady EN, MacDonald J, Liu L, Richman A, Yuan ZC. Current knowledge and perspectives of Paenibacillus: a review. Microb Cell Factories. 2016;15:203.

41. Achermann Y, Goldstein EJ, Coenye T, Shirtliff ME. Propionibacterium acnes: from commensal to opportunistic biofilm-associated implant pathogen. Clin Microbiol Ver. 2014;27:419-40.

42. Shin K, Yun Y, Yi S, Lee HG, Cho JC, Suh KD, et al. Biofilm-forming ability of Staphylococcus aureus strains isolated from human skin. J Dermatol Sci. 2013;71:130-7

43. Trampuz A, Zimmerli W. Diagnosis and treatment of infections associated with fracture-fixation devices. Injury. 2006;37(Suppl 2):S59-66.

44. Russu E, Mureșan A, Grigorescu B. Vascular graft infections management. Clin Manage. 2011;3:16-9.

45. Anderl JN, Franklin MJ, Stewart OS. Role of antibiotic penetration limitation in Klebsiella pneumoniae biofilm resistance to ampicillin and ciprofloxacin. Antimicrob Agents Ch. 2000;44:1818-24.

46. Costa JC, Espeschit IF, Pieri FA, Benjamin LA, Moreira MA. Increased production of biofilms by Escherichia coli in the presence of enrofloxacin. Vet Microbiol. 2012;160:488-90.

47. Neely AN, Plessinger RT, Stamper B, Kagan RJ. Can contamination of a patient's allograft be traced back to the allograft donor? J Burn Care Res. 2008;29:73-6.

Ready to submit your research? Choose BMC and benefit from:

- fast, convenient online submission

- thorough peer review by experienced researchers in your field

- rapid publication on acceptance

- support for research data, including large and complex data types

- gold Open Access which fosters wider collaboration and increased citations

- maximum visibility for your research: over $100 \mathrm{M}$ website views per year

At BMC, research is always in progress.

Learn more biomedcentral.com/submissions 